\title{
Imaging Tree Root Zone Geometry Using Electrical Resistivity Tomography
}

\author{
Asep Mulyono $^{1^{*}}$, Ilham Arisbaya ${ }^{1}$, Yayat Sudrajat ${ }^{1}$ \\ ${ }^{1}$ Research Center for Geotechnology, Indonesian Institute of Sciences (LIPI)
}

\begin{abstract}
Root zone geometry research is usually done in a conventional way which is destructive, time-consuming, and requires a considerable cost. Several non-destructive measurements used geophysical methods have been developed, one of which is the Electrical Resistivity Tomography (ERT) method. Tree root zone determination using ERT has been carried out in Kiara Payung area, Sumedang, West Java, with Maesopsis eminii tree as the object study. A total of 29 ERT lines were measured using dipoledipole configuration with electrodes spacing of 50 $\mathrm{cm}$. The results of two-dimensional (2D) and three-dimensional (3D) inversion modeling show that the ERT method has been successfully imaging the tree root zone. The root zone is characterized as $100-700 \Omega \mathrm{m}$ with an elliptical shape geometry of the root plate. The root radius is estimated to be $4-5 \mathrm{~m}$ from the stem, the root zone diameter reaches 8-9 $\mathrm{m}$ at the shallow soil surface and the root zone depth is approximately $2-2.5 \mathrm{~m}$
\end{abstract}

Keywords: electrical resistivity tomography (ERT), root zone, tree, Maesopsis eminii.

\begin{abstract}
ABSTRAK Pencitraan geometri zona perakaran pohon menggunakan electrical resistivity tomography. Penelitian geometri zona perakaran biasa dilakukan dengan cara konvensional yang destruktif, memakan waktu, dan membutuhkan biaya yang tidak sedikit. Beberapa pengukuran non-destruktif menggunakan metode geofisika telah dikembangkan, salah satunya adalah metode Electrical Resistivity Tomography (ERT). Penentuan zona perakaran pohon menggunakan metode ERT telah dilakukan di daerah Kiara Payung, Sumedang, Jawa Barat, dengan pohon Maesopsis eminii sebagai objek studi. Sebanyak 29 lintasan ERT diukur menggunakan konfigurasi dipole-dipole pada dengan jarak antar elektroda $50 \mathrm{~cm}$. Hasil pemodelan inversi dua dimensi $(2 D)$ dan tiga dimensi (3D) menunjukkan bahwa metode ERT telah berhasil mencitrakan zona perakaran pohon. Zona perakaran teridentifikasi berada pada nilai resistivitas 100-700 $\Omega$ m dengan root plate dan root cross-sections berbentuk elips. Radius akar diperkirakan sejauh 4-5 $m$ dari pangkal batang, sedangkan diameter zona perakaran mencapai sekitar $8-9 m$ di permukaan tanah dangkal dan kedalaman zona perakaran diperkirakan antara $\sim 2-2.5 \mathrm{~m}$.
\end{abstract}

Kata kunci: electrical resistivity tomography $(E R T)$, zona perakaran, pohon, Maesopsis eminii.

\section{INTRODUCTION}

Tree root is one of the most difficult organs to understand (Lazarovitch et al., 2018; Stover et al., 2007). However, it plays an important role and responsible for several functions in storage, synthesis of growth substances, sources of organic matter (Fitter, 2002), water and mineral nutrients absorption, and as an anchor to tree over-turning (Prieto et al., 2012). The root development process will directly change the soil structure and porosity and increase soil biomass production (Hultine et al., 2003). 
The root zone geometry research is usually done with destructive measurement by soil excavation, monoliths, augers, trenching, etc., which is timeconsuming, expensive, and challenging (Box, 1996), especially under large living trees (Pawlik dan Kasprzak, 2018). Several non-destructive methods have been developed, e.g. magnetic resonance, video and digital cameras (Box, 1996), glass walls, rhizotrons, minirhizotrons (Johnson et al., 2001), ground-penetrating radar (Al Hagrey, 2007; Hruska et al., 1999; Zenone et al., 2008), Xray imaging (Pierret et al., 1999; Schmidt et al., 2012), seismic (Leucci, 2010; Weihs et al., 1999), and electrical resistivity (Ain-Lhout et al., 2016; Al Hagrey, 2007; Amato et al., 2008).

The electrical resistivity tomography (ERT) method has shown promising results. ERT is a fairly simple method, relatively inexpensive, easy to implement, and efficient for site investigation (Papadopoulos et al., 2007). This method has been trailed for rooting system research under the trees, herbaceous plants and gardens (Ain-Lhout et al., 2016; Amato et al., 2008; Corwin dan Lesch, 2005; Leucci, 2010; Michot et al., 2003; Morelli et al., 2007). ERT method also widely used to study soil moisture distribution, root zone geometry, wood decay, and stem anatomy (Al Hagrey, 2007; Michot et al., 2003). A close correlation between bulk resistivity and root mass density has been shown (Amato et al., 2008). However, to date it has not been able to image a single root in detail (Al Hagrey, 2007).

The root zone (rhizosphere) is an interface area between soil and vegetation which controls the movement of water, nutrients, and other commodities to the tree (Hinsinger et al., 2009; McNear, 2013). The tree root zone also changed the soil resistivity values (Al Hagrey and Petersen, 2011; Al Hagrey, 2007). Root density measurement is complicated and hard to obtain (Raats, 2007), thus geometrical information is needed both temporally and spatially under soil profile.

In Indonesia, the applications of ERT in root zone research is lacking in number. Therefore, the specific objective of this research is to conduct a preliminary study in determining the geometry of the tree root zone in $2 \mathrm{D}$ and $3 \mathrm{D}$ manner using the ERT method.

\section{LOCATION AND OBJECT STUDY}

The study site is located in Kiara Payung, Sumedang, West Java, at an altitude of $925 \mathrm{~m}$ above sea level. It is situated at the southeastern flank of Mount Manglayang, a presumably Early to Middle Quaternary inactive (dormant) volcano (Dam et al., 1996). Manglayang and surrounding area was mapped to have been covered by undifferentiated young volcanic deposits consist of tuffaceous sand, lapilli, lava, and agglomerate (Alzwar et al., 1992). A recent study mapped the surrounding area to have formed by pyroclastic breccia-andesite enstatite lava and andesite enstatite lava rock units (Wiavianto et al., 2017). The study also revealed that the andesite lava of Manglayang was formed at a relatively lower temperature as compared to the basalt lava of Mount Palasari in the west and the andesite lava of Mount Pangparang in the north.

The weathering of this intermediary andesitic lava in Manglayang produces Andisols soil types with the soil family were Typic Hapludands (Soil and Agroclimatic Research Center, 1993; Soil Survey Staff, 2014). Andisols was volcanic soils which developed from young parent material (tuffaceous sand, lapilli, breccia, lava, and agglomerates) (Arifin dan Devnita, 2008).

The research object is tree species of Maesopsis eminii. The tree height is $14 \mathrm{~m}$, stem diameter (DBH) $63.5 \mathrm{~cm}$, and crown width $14.7 \mathrm{~cm}$. The Maesopsis eminii tree grows at an altitude of 600 to $1.500 \mathrm{~m}$ above sea level with rainfall of 1.200 to $3.600 \mathrm{~mm} /$ year. The rural community planted this tree mainly for wood production, and as green belt trees. Maesopsis eminii was a deciduous tree, height reaching $45 \mathrm{~m}$ with free branches $2 / 3$ in total height (Bramasto et al., 2015).

\section{METHODS}

The basic principle of ERT is to measure the resistivity by injecting electric current (I) into the soil surface through two current electrodes and measuring the voltage difference $(\Delta \mathrm{V})$ through potential electrodes. The apparent resistivity $(\rho)$ was then calculated using the following equation:

$$
\rho_{a}=K \frac{\Delta V}{I} \ldots \ldots \ldots(\mathrm{Ohm})
$$

with $\mathrm{K}$ is geometry factor that depends on the electrode configuration. 

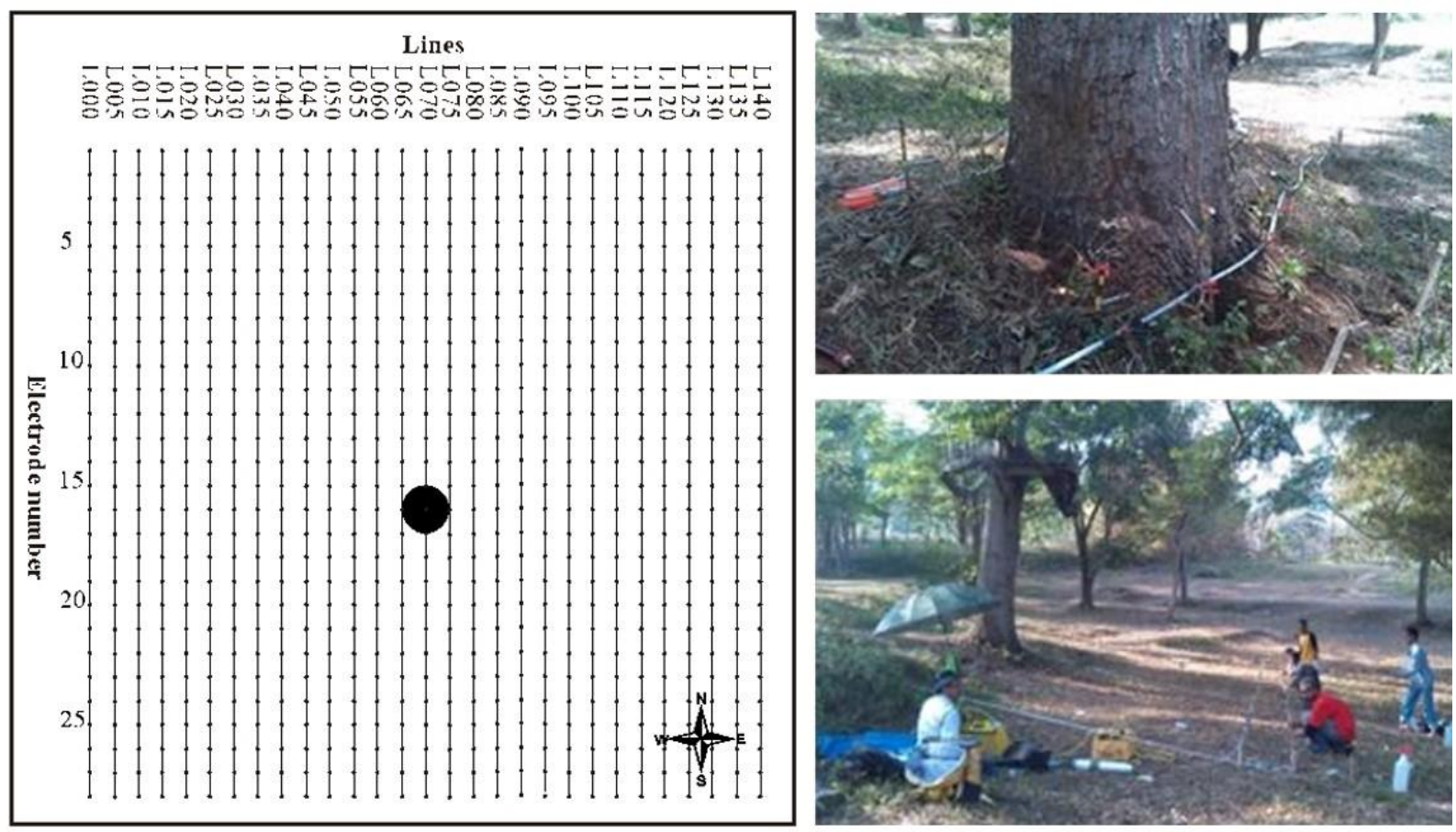

Figure 1. Schematic position of ERT measurements around the Maesopsis eminii tree.

$(\bullet$ : tree position; - ERT lines)

The ERT method was performed using Supersting R8/IP (Advance Geoscience Inc.) instrument. In the case of 3D resistivity imaging using multiple parallel 2D lines, the comparison between the inter-line distance and the electrode spacing will significantly influence the resulting inversion model (Okpoli, 2013). Furthermore, the author recommends that the interline distance should be the same as the electrode spacing (uniform grid). The uniform electrode distance in both lateral directions will result in higher sensitivity compared to the irregular grid. Taking into account the tree canopy width of about $14 \mathrm{~m}$, we designed a total of 29 lines with a $50 \mathrm{~cm}$ interline distance. Each line consists of 28 electrodes with a spacing of $50 \mathrm{~cm}$ and dipole-dipole electrode configuration was chosen (Figure 1). This array is very sensitive to the lateral resistivity variations, therefore it is very suitable to reconstruct a real model of the vertical three-dimensional structure with high resistivity values, such as roots and cavities (Leucci, 2010; Moreira et al., 2016). The line direction is in North-South direction and the Maesopsis eminii tree was on the 15th to 17 th electrodes (L065-L075). Field observation was conducted in May 2017 (dry season). In this preliminary result, we did not take into account the seasonal weather effect into the resistivity measurement.

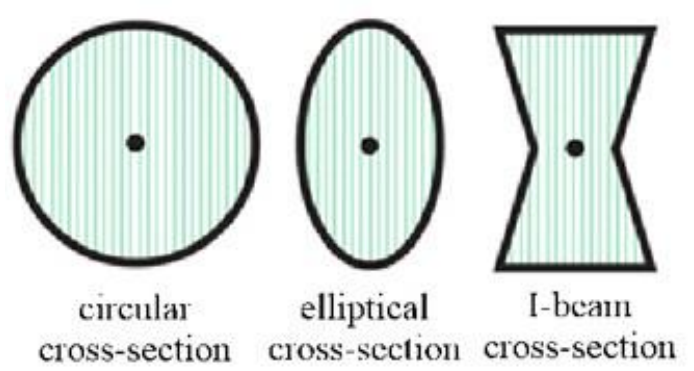

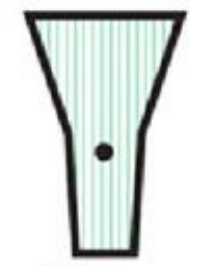

T-beam cross-section

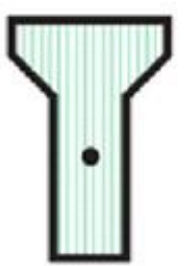

T-beam plank cross-section
Figure 2. Illustration of root cross-sections shapes under tree stem (Coder, 2018). 


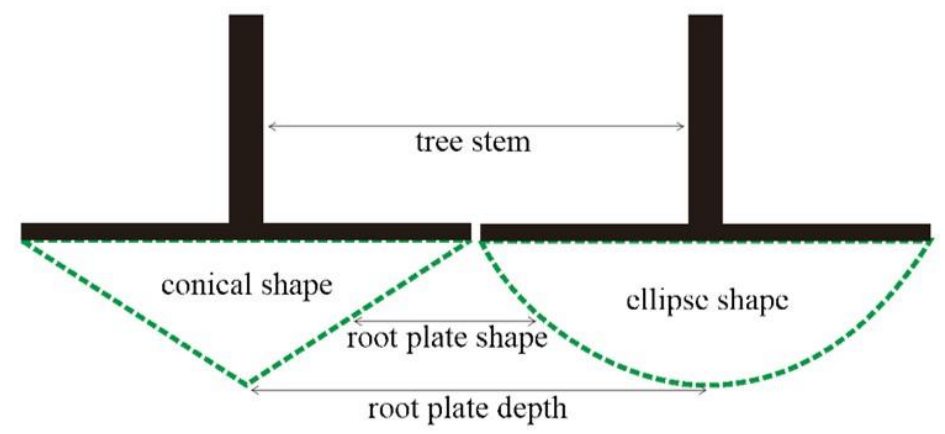

Figure 3. Side view illustration of root plate cross-sectional area under tree stem (Coder, 2018).

The acquired data were then processed in the mode of two-dimensional (2D) and threedimensional (3D) inversion modeling using AGI EarthImager Inversion software. 2D and 3D displays can provide an overview of the root crosssections and depth of the root plate of the tree, as illustrated in Figures 2 and 3.
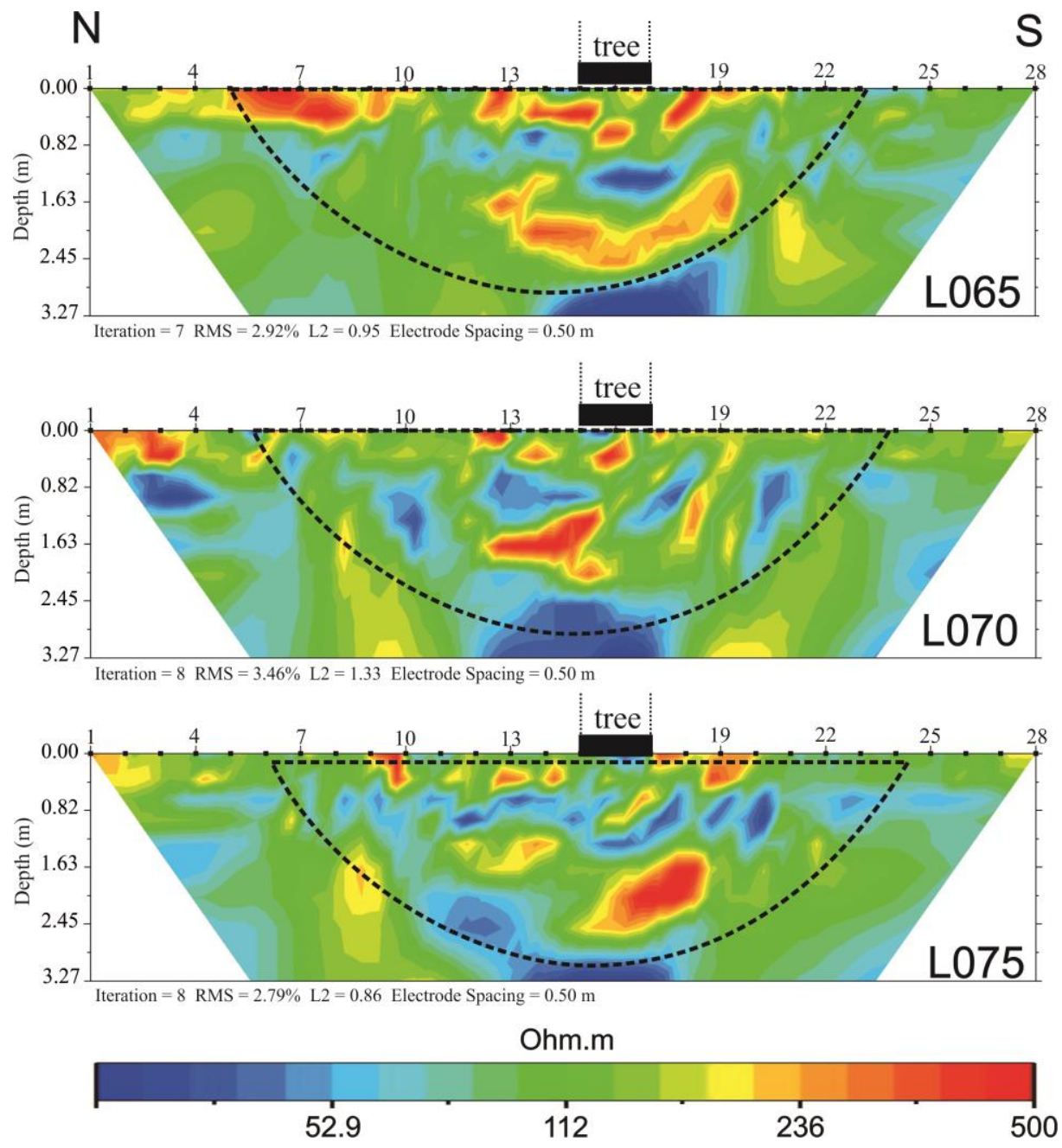

Figure 4. 2D inversion cross-section on three ERT line across the Maesopsis eminii tree.

( $\mathbf{m}$ : tree position; root plate cross-sectional area) 
To compare the results obtained from the interpretation of the ERT model, root radius from the stem (Roering et al., 2003) and root plate depth (Coder, 2018) of the root zone are calculated using the stem diameter $\left(\mathrm{DBH}_{\text {in }}\right)$ using these equations:

Root radius from $\mathrm{stem}_{\text {feet }}=19.057 \mathrm{x}(0.0254 \mathrm{x}$ $\left.\mathrm{DBH}_{\text {in }}\right)^{0.59}$

Root plate depth $\mathrm{feet}_{\text {fot }}=0.3 \times \mathrm{DBH}_{\mathrm{in}}$.

\section{RESULTS AND DISCUSSION}

\section{Two-Dimensional (2D) Inversion}

In general, the result of $2 \mathrm{D}$ inversion shows high resistivity values $(>200 \Omega . \mathrm{m})$ dominate the nearsurface area (up to $\sim 0.75 \mathrm{~m}$ ). This high resistivity zones can be interpreted as the manifestation of dry soil and the presence of dense roots distribution. The low resistivity anomalies $(<100$ $\Omega \mathrm{m})$ that exist within the root zone $(0.75-1.5 \mathrm{~m})$ can be interpreted as a representation of soil layers with higher water content. High resistivity anomalies are also observed below the lower resistivity layer, in a more limited distribution.

As shown in Figure 4, the root radius from tree stem extends farther to the north rather than the south. The root distributed as far as $8.89 \mathrm{~m}$ at a depth of $0-0.75 \mathrm{~m}$, characterized by resistivity values of 200-500 $\Omega \mathrm{m}$ (yellow to red color zone). In Figure 4, the lateral resistivity changes likely illustrate the variations of root density which depends on the concentration of the nutrients in the soil surface layer (Leucci, 2010).

Figure 4 shows typical images from 2D inversion cross-section of three ERT lines, with the ellipseshaped root plate cross-sectional area under Maesopsis eminii tree. The root plate depth is still observed to a depth of $\sim 2.5 \mathrm{~m}$ depth (yellow color zone) in L065-L075 (Figure 4). The side view illustration of the root plate cross-sectional is shown in Figure 5.

\section{Three-Dimensional (3D) Inversion}

Figure 6 is the result of 3D ERT inversion model, shown by horizontal resistivity slices in certain depths. In general, the result of $2 \mathrm{D}$ and 3D inversion share the same common features. The near-surface is dominated by the high resistivity anomaly ( $>200 \Omega . m$ ), followed by dominant low resistivity anomalies $(<100 \Omega . \mathrm{m})$ at a depth of

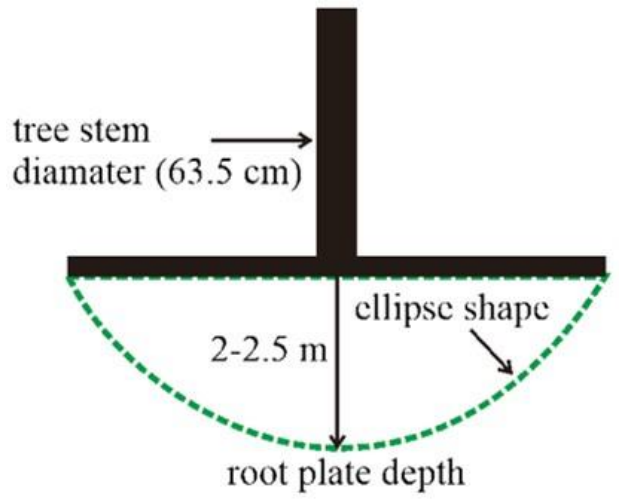

Figure 5. Illustration of tree root plate crosssectional area under Maesopsis eminii tree.

about $0.75-1.5 \mathrm{~m}$ and medium to high resistivity values (100-300 $\Omega . m$ ) in the lower part.

The root zone is characterized by the high resistivity anomaly, with a value of 200-700 $\Omega$ m. Similar results have been reported from resistivity measurements on eucalyptus trees in Lecce, Italy (Leucci, 2010) and pine and oak trees in Sierra San Miguelito Volcanic Complex, Mexico (Rodríguez-Robles et al., 2017). These authors characterize the tree root zone as a higher resistivity anomaly compared to the surrounding soil, excluding very high resistivity values of rocks.

The lateral root concentrated at depth of $0-0.75 \mathrm{~m}$. The density of lateral root at $\sim 0.25 \mathrm{~m}$ depth (Figure 6B) is greater than at the depths below (Figure 6C-D), and decreases sharply after depth of $\sim 0.75 \mathrm{~m}$. Root density (number of roots per unit volume) has a great abundance in the near-surface layer with mostly fine roots and decreases with depth (Leucci, 2010). Going deeper into the soil, smaller and less root density is present (Abernethy dan Rutherfurd, 2001; Tobin et al., 2007; Tosi, 2007).

The low resistivity $(<100 \Omega \mathrm{m})$ is increased dominantly at depth of $1.0-1.5 \mathrm{~m}$ (Figure 6E-G), due to the higher water content that obscures the low resistivity changes in the root zone. The medium to high resistivity anomaly is clearly still observed at depth of $\sim 1.75-2.5 \mathrm{~m}$ (Figure $6 \mathrm{H}-\mathrm{K}$ ), but the extent decreased following root plate depth. We interpret this as the tap root of the tree. 

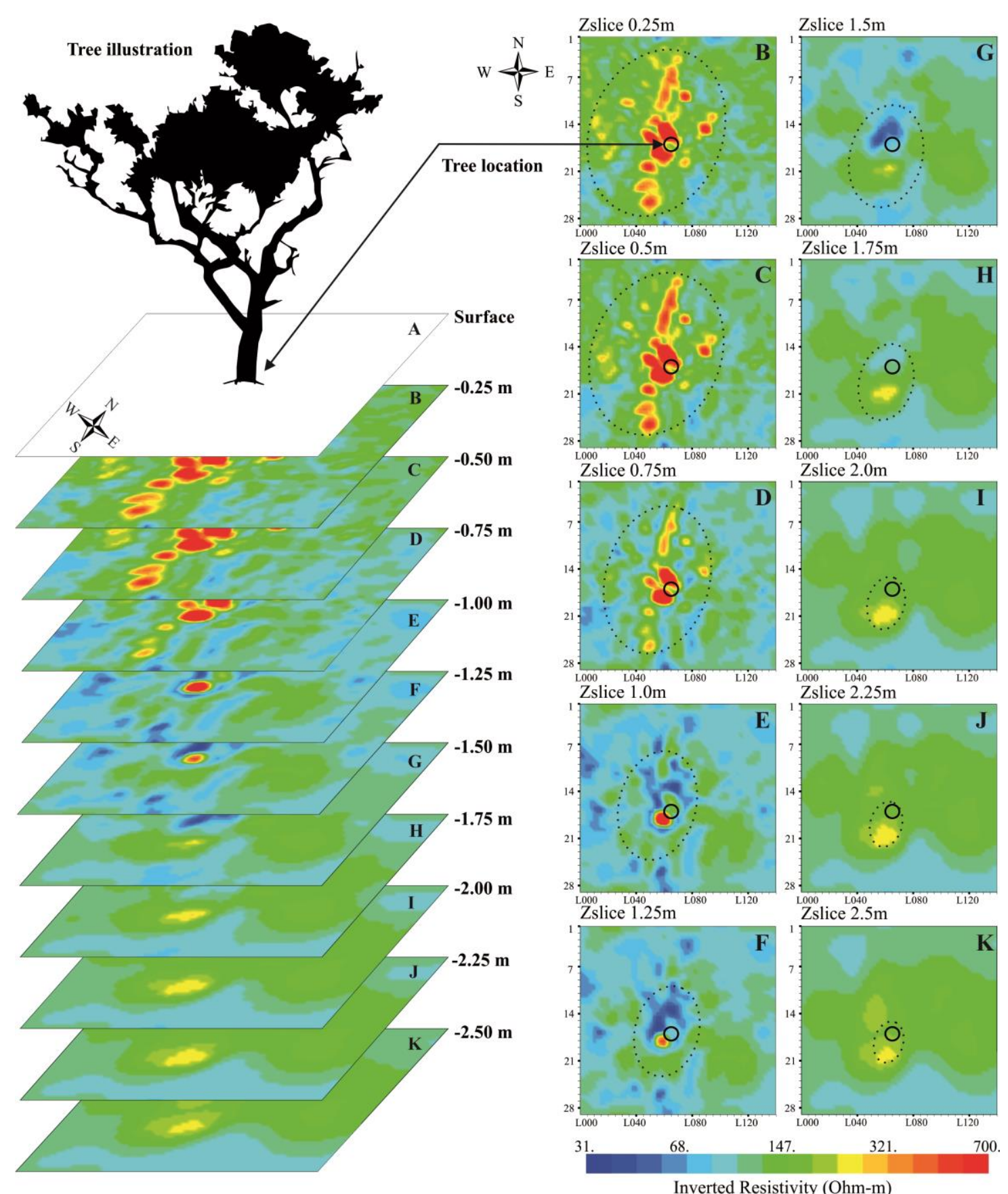

Figure 6. 3D inversion results at a depth of 0.25-2.5 meters sliced each $25 \mathrm{~cm}$ depth. ( $\circ$ : tree position; root zone)

Maesopsis eminii was the tree species that have a dominant lateral root (root fibers) and tap-roots (Epila et al., 2017).

The $2 \mathrm{D}$ and $3 \mathrm{D}$ inversion resulted in a model slices with depth up to $3.25 \mathrm{~m}$ and $2.5 \mathrm{~m}$ respectively. The $3 \mathrm{D}$ model shows that the root zone is still observed at $\sim 2.5 \mathrm{~m}$ depth, but the $2 \mathrm{D}$ model shows that the root zone is not observed at the greater depth. This corresponds well with the estimates calculated from equation 3 (Coder, 2018), which yields an estimated value of $\sim 2.29$ $\mathrm{m}$.

The spread of root growth is depends upon soil compaction which acting as a physical barrier to 
root growth and by blocking oxygen movement to the root surface (Coder, 2018). Possibly the tree roots experience difficulties to physically penetrate the soil with a mass density greater than $1.7 \mathrm{~g} / \mathrm{cc}$ (Coder, 2018).

Root radius from stem, based on equation 2, was $4.44 \mathrm{~m}$, while the diameter of the root zone was $8.89 \mathrm{~m}$. It is closely related to ERT result, which shows the radius of root approximately 4.5 to 5.0 $\mathrm{m}$ from the tree stem, while the diameter of the root zone was 7-9 $\mathrm{m}$ at shallow subsurface layers $(\sim 0.25-0.5 \mathrm{~m})$. The $3 \mathrm{D}$ inversion shows the ellipse shape of the root zone (Figures $6 \mathrm{~B}$ and $\mathrm{H}$ ) and decreased sharply with depth.

Root zone is generally a consequence of relatively high moisture contents. However, only woody, thick and isolated roots are characterized by electric resistivity response, compared to the soil (Al Hagrey, 2007). The depth of root plate is limited by aerobic soil values (Peltola, 2006) and soil texture (Dupuy et al., 2007).

The root spreading direction (ellipse shape) is closely related to the crown shape of tree observation with north-south trending (Figure 7). Soil drainage, oxygenation, and carbon dioxide loss as impacted by soil texture, bulk density, and physical soil constraints affected root distribution in the soil (Bischetti et al., 2005).

\section{CONCLUSIONS}

Electrical resistivity tomography (ERT) has been successfully imaged the root zone under the Maesopsis eminii tree. The root plate and root shape cross-sectional of the Maesopsis eminii tree has an elliptical shape. The resulted image corresponds well with the estimation calculated from the stem diameter. This ERT result has not been succeeded in imaging the root branching geometry in detail. However, we have shown that ERT is able to interpret the shape and depth of the tree root zone. Further study is needed to confirm this ERT result including time-lapse measurement to count the seasonal effect, the use of other geophysical methods, e.g. ground-penetrating radar (GPR), and/or direct method by trenching as validation.

\section{ACKNOWLEDGMENTS}

This study was partially supported by Applied Research in Disaster Focus Programme, Research

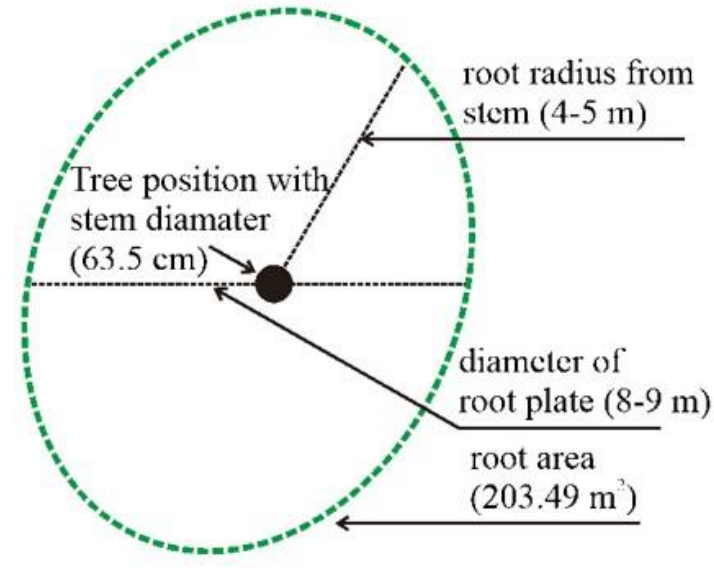

Figure 7. Illustration of ellipse cross-section shape of tree root by 3D inversion on depth $0-0.25 \mathrm{~m}$.

Centre for Geotechnology, Indonesian Institute of Sciences, Projects No. 3408. 904.U25.051-SP DIPA-079.01.2.017152/2017. The author would like to thank our colleagues (Eko Yulianto, Dyah Marganingrum, Fajar Lubis, Hendra Bakti) who provided insight and expertise and helped clarify the ideas and for technicians (Nyanjang, Dede Rusmana, Aep Sofyan and Sukoco) for their thoughtful assistance during field study. We acknowledged comments from the reviewers and the editor.

\section{REFERENCES}

Abernethy, B., Rutherfurd, I.D., 2001. The distribution and strength of riparian tree roots in relation to riverbank reinforcement. Hydrological processes $15,63-79$.

Ain-Lhout, F., Boutaleb, S., Diaz-Barradas, M.C., Jauregui, J., Zunzunegui, M., 2016. Monitoring the evolution of soil moisture in root zone system of Argania spinosa using electrical resistivity imaging. Agricultural Water Management 164, 158-166. doi:10.1016/j.agwat.2015.08.007

Al Hagrey and Petersen, 2011. Numerical and experimental mapping of small root zones using optimized surface and borehole resistivity tomography. Geophysics 76, G25-G35. doi:10.1190/1.3249778 
Al Hagrey, S.A., 2007. Geophysical imaging of root-zone, trunk, and moisture heterogeneity. Journal of Experimental Botany 58, 839-854. doi:10.1093/jxb/erl237

Alzwar, M., Akbar, N., A., Bachri, S., 1992. Geological Map of Garut and Pameungpeuk Sheet, West Java, scale 1:100.000. Bandung.

Amato, M., Basso, B., Celano, G., Bitella, G., Morelli, G., Rossi, R., 2008. In situ detection of tree root distribution and biomass by multi- electrode resistivity imaging. Tree Physiology 28, 14411448.

Arifin, M., Devnita, R., 2008. Micromorphological Characterization of Some Volcanic Soil In West Java. Indonesian Journal on Geoscience 3, 195-203.

Bischetti, Chiaradia, E.A., Simonato, T., Speziali, B., Vitali, B., Vullo, P., Zocco, A., 2005. Root strength and root area ratio of forest species in Lombardy (Northern Italy), in: Eco-and ground bioengineering: The use of vegetation to improve slope stability. Springer, hal. $31-41$.

Box, J.E., 1996. Modern Methods for Root Investigations. Plant roots: the hidden half. Ed. Waisel, Y, Eshel, A and Kafkafi, U 193-237.

Bramasto, Y., Nurhasybi, Danu, Syamsuwida, D., Zanzibar, M., Pujiastuti, Mokodompit, S., 2015. Trees of the city. Balai Penelitian Teknologi Perbenihan Tanaman Hutan, Bogor.

Coder, K.D., 2018. Root strength \& tree anchorage. University of Georgia, Warnell School of Forestry \& Natural Resources outreach publication WSFNR-18-37.

Corwin, D.L., Lesch, S.M., 2005. Apparent soil electrical conductivity measurements in agriculture. Computers and electronics in agriculture 46, 11-43.

Dam, M.A.C., Suparan, P., Nossin, J.J., Voskuil, R., 1996. A chronology for geomorphological developments in the greater Bandung area, West-Java, Indonesia. Journal of Southeast Asian Earth Sciences 14, 101-115. doi:10.1016/S0743-9547(96)00069-4

Dupuy, L., Fourcaud, T., Stokes, A., 2007. A numerical investigation into the influence of soil type and root architecture on tree anchorage, in: Ecoand ground bio-engineering: The use of vegetation to improve slope stability. Springer, hal. 175-189.

Epila, J., Verbeeck, H., Otim-Epila, T., Okullo, P., Kearsley, E., Steppe, K., 2017. The ecology of Maesopsis eminii Engl. in tropical Africa. African journal of ecology 55, 679-692.

Fitter, A., 2002. Characteristics and functions of root systems, in: Plant roots. CRC Press, hal. 49-78.

Hinsinger, P., Bengough, A.G., Vetterlein, D., Young, I.M., 2009. Rhizosphere: biophysics, biogeochemistry and ecological relevance. Plant and soil 321, 117-152.

Hruska, J., Čermák, J., Šustek, S., 1999. Mapping tree root systems with groundpenetrating radar. Tree physiology 19, $125-130$.

Hultine, K.R., Cable, W.L., Burgess, S.S.O., Williams, D.G., 2003. Hydraulic redistribution by deep roots of a Chihuahuan Desert phreatophyte. Tree Physiology 23, 353-360.

Johnson, M.G., Tingey, D.T., Phillips, D.L., Storm, M.J., 2001. Advancing fine root research with minirhizotrons. Environmental and Experimental Botany 45, 263-289.

Lazarovitch, N., Vanderborght, J., Jin, Y., van Genuchten, M.T., 2018. The Root Zone: Soil Physics and Beyond. Vadose Zone Journal 17.

Leucci, G., 2010. The use of three geophysical methods for 3D images of total root volume of soil in urban environments. Exploration Geophysics 41, 268-278. 
McNear, D.H., 2013. The rhizosphere-roots, soil and everything in between. Nature Education Knowledge 4, 1.

Michot, D., Benderitter, Y., Dorigny, A., Nicoullaud, B., King, D., Tabbagh, A., 2003. Spatial and temporal monitoring of soil water content with an irrigated corn crop cover using surface electrical resistivity tomography. Water Resources Research 39, 1-20. doi:10.1029/2002WR001581

Moreira, C.A., Lapola, M.M., Carrara, A., 2016. Comparative analyzes among electrical resistivity tomography arrays in the characterization of flow structure in free aquifer 119-129.

Morelli, G., Zenone, T., Teobaldelli, M., Fischanger, F., Matteucci, M., Seufert, G., 2007. Use of ground-penetrating radar (GPR) and electrical resistivity tomography (ERT) to study tree roots volume in pine forest and poplar plantation. Napier, New Zealand 21, 14.

Okpoli, C.C., 2013. Sensitivity and resolution capacity of electrode configurations. International Journal of Geophysics 2013.

Papadopoulos, N.G., Tsourlos, P., Tsokas, G.N., Sarris, A., 2007. Efficient ERT measuring and inversion strategies for 3D imaging of buried antiquities. Near Surface Geophysics 5, 349-361.

Pawlik, Ł., Kasprzak, M., 2018. Regolith properties under trees and the biomechanical effects caused by tree root systems as recognized by electrical resistivity tomography (ERT). Geomorphology 300, 1-12.

Peltola, H.M., 2006. Mechanical stability of trees under static loads. American journal of botany $93,1501-1511$.

Pierret, A., Capowiez, Y., Moran, C.J., Kretzschmar, A., 1999. X-ray computed tomography to quantify tree rooting spatial distributions. Geoderma 90, 307326.
Prieto, I., Armas, C., Pugnaire, F.I., 2012. Water release through plant roots: new insights into its consequences at the plant and ecosystem level. New Phytologist 193, 830-841.

Raats, P.A.C., 2007. Uptake of water from soils by plant roots. Transport in porous media $68,5-28$.

Rodríguez-Robles, U., Tulio, A., HuberSannwald, E., Ramos-Leal, J.A., Yépez, E.A., 2017. Application of geophysical tools for tree root studies in forest ecosystems in complex soils. Biogeosciences 14, 5343-5357. doi:10.5194/bg-14-5343-2017

Roering, J.J., Schmidt, K.M., Stock, J.D., Dietrich, W.E., Montgomery, D.R., 2003. Shallow landsliding, root reinforcement, and the spatial distribution of trees in the Oregon Coast Range. Canadian Geotechnical Journal 40, 237-253.

Schmidt, S., Bengough, A.G., Gregory, P.J., Grinev, D. V, Otten, W., 2012. Estimating root-soil contact from 3D Xray microtomographs. European Journal of Soil Science 63, 776-786.

Stover, D.B., Day, F.P., Butnor, J.R., Drake, B.G., 2007. Effect of elevated CO2 on coarseroot biomass in Florida scrub detected by ground-penetrating radar. Ecology 88, 1328-1334.

Tobin, B., Čermák, J., Chiatante, D., Danjon, F., Di Iorio, A., Dupuy, L., Eshel, A., Jourdan, C., Kalliokoski, T., Laiho, R., 2007. Towards developmental modelling of tree root systems. Plant Biosystems 141, 481-501.

Tosi, M., 2007. Root tensile strength relationships and their slope stability implications of three shrub species in the Northern Apennines (Italy). Geomorphology 87, 268-283.

Weihs, U., Dubbel, V., Krummheuer, F., Just, A., 1999. The electrical resistivity tomography-A promising technique for the detection of colored heart wood on standing beech trees. Forst und $\mathrm{Holz}$ (Germany). 
Wiavianto, S., Mubandi, A.S.S., Irawan, D.E., 2017. Geologi dan petrologi kawasan Manglayang, Bandung Timur, Jawa Barat. Skripsi ITB (tidak dipublikasi).

Zenone, T., Morelli, G., Teobaldelli, M., Fischanger, F., Matteucci, M., Sordini, M., Armani, A., Ferrè, C., Chiti, T., Seufert, G., 2008. Preliminary use of ground-penetrating radar and electrical resistivity tomography to study tree roots in pine forests and poplar plantations. Functional Plant Biology 35, 1047-1058. 